\title{
Expression of prolactin-related protein I at the fetomaternal interface during the implantation period in cows
}

\author{
O. Yamada ${ }^{1,2}$, J. Todoroki ${ }^{3}$, K. Kizaki $^{1 *}$, T. Takahashi $^{1}$, K. Imai $^{1}$, \\ O. V. Patel ${ }^{1}$, L. A. Schuler ${ }^{4}$ and K. Hashizume ${ }^{1 \dagger}$ \\ ${ }^{1}$ Laboratory of Reproductive Biology and Technology, National Institute of Agrobiological \\ Sciences, Ikenodai 2, Kukizaki, Inashiki Ibaraki 305-8602, Japan; ${ }^{2}$ Bio-oriented Technology \\ Research Advancement Institution, Saitama, Saitama 331-8537, Japan; ${ }^{3}$ Kagoshima \\ Prefectural Cattle Breeding and Development Institute, Oosumu, Kagoshima 899-8212, \\ Japan; and ${ }^{4}$ Department of Comparative Biosciences, School of Veterinary Medicine, \\ University of Wisconsin, Madison, WI 53706, USA
}

\begin{abstract}
The bovine placenta secretes multiple molecules during implantation and placentation, many of which are produced by binucleate cells. In this study, production of prolactin-related protein I (PRP-I), a member of the nonclassical prolactin-related family, was investigated during the implantation period in cows. Expression of bovine PRPI (bPRP-I) in the placentome was examined during the preimplantation (days 17-19), implantation (days 20-25) and post-implantation (days 30-60) periods by immunohistochemistry, immunofluorescence and in situ hybridization. During the preimplantation period, both bPRP-I and bovine placental lactogen (bPL) were
\end{abstract}

undetectable in trophoblastic cells. Both bPRP-I mRNA and protein appeared first at day 20 of gestation in trophoblastic binucleate cells and multinuclear cells that might migrate into the endometrium and fuse to epithelium; however, no bPL was detected in binucleate cells at this time. After implantation, on day 30, both bPRP-I and bPL were detected in binucleate cells and were co-expressed in the same cells. These data indicate that bPRP-I may play a role before implantation and that bPRP-I may be an excellent marker for trophoblastic cell differentiation, as well as a candidate for pregnancy diagnosis.

\section{Introduction}

The placenta produces many molecules that play important roles in implantation, fetal growth and maintenance of gestation (Wooding, 1992). The prolactin/growth hormone $(\mathrm{GH})$ family is expressed in the placenta in various species including mice and ruminants, as well as primates (Anthony et al., 1995; Soares et al., 1998). The function of most of these molecules, including the non-classical prolactinrelated family, is not well understood. However, the prolactin/GH family is generally thought to contribute to growth of the fetus and placenta, control of maternal metabolism, development of the maternal mammary gland, maintenance of steroidogenesis (Wooding, 1992) and modulation of immune activity (Müller et al., 1999). In bovine placenta, two placental lactogens and various prolactin-related proteins have been reported (Murthy et al.,

*Present address: Laboratory of Veterinary Pharmacology, School of Veterinary Medicine and Animal Sciences, Kitasato University, Higashi 23-35-1, Towada, Aomori 034-8628, Japan

${ }^{+}$Correspondence

Email:kazuha@affrc.go.jp
1982; Schuler et al., 1988, 1991; Kessler et al., 1989; Yamakawa et al., 1990; Tanaka et al., 1991; Schuler and Kessler, 1992). They are all produced by the placental binucleate cells, which play crucial roles in placentation, including formation of the fetomaternal syncytium and production of placental hormones (Duello et al., 1986; Milosavljevic et al., 1989; Morgan et al., 1989; Wooding, 1992; Zoli et al., 1992). Previous reports have shown that prolactin-related genes are expressed in the conceptus (Kessler et al., 1991) and that these molecules may coordinate various functions at the fetomaternal interface (Kessler and Schuler, 1997).

Bovine prolactin-related protein I (bPRP-I) is the only protein in the prolactin family other than bovine placental lactogen (bPL) that has been shown to be expressed in the bovine placenta. bPRP-I mRNA was found within the fetal membranes by molecular cloning (Schuler and Hurley, 1987) and was localized to the binucleate cells (Milosavljevic et al., 1989; Zieler et al., 1990). Recently, it was also reported in uterine fluid during gestation (Kessler and Schuler, 1997). However, little is known about the initiation of production of bPRP-I by the binucleate cell and its role in bovine implantation. In the present study, bPRP-I gene expression was examined during the implantation period and compared with that of bPL. 


\section{Materials and Methods}

\section{Collection of tissues}

Japanese black beef cows $(n=11)$ were grouped into preimplantation (day $17(n=2)$ and day $19(n=1))$, implantation (days 20, 21 and 24), post-implantation (day $30(n=3))$ and placentation (day $60(n=3))$ groups. These four groups were based on morphological development of the fetomaternal interface (Wooding, 1992). Pregnancy was initiated by artificial insemination on the day of oestrus, designated as day 0 of gestation. Immediately after collection, tissues for northern blot analysis were frozen in liquid nitrogen and stored at $-80^{\circ} \mathrm{C}$ for 2 months before RNA extraction. Tissues for histological examination were fixed and processed as follows.

\section{Immunohistochemical detection}

Uteri and placentae were obtained at an abattoir at 30-40 min after death. Tissue samples were perfused with $4 \%(\mathrm{w} / \mathrm{v})$ paraformaldehyde in $10 \mathrm{mmol}^{\mathrm{PBS} \mathrm{I}}{ }^{-1}$ $(\mathrm{pH} 7.4)$ via ovarian and uterine arteries. After perfusion, the uteri were separated into non-gravid and gravid horns. Each horn was sliced into sections of about $10 \mathrm{~mm}$ thickness and post-fixed in $4 \%(\mathrm{w} / \mathrm{v})$ paraformaldehyde in PBS overnight at $4^{\circ} \mathrm{C}$. Post-fixed tissues were dehydrated in alcohol and xylene, and embedded in paraffin wax within 2 months after collection. Mounted samples were cut into $5 \mu \mathrm{m}$ sections with a rotary microtome HM355 (MICROM Laborgeräe GmbH, Heidelberg) and placed onto poly-L-lysin-coated slides (Matsunami, Tokyo).

Paraffin wax sections were incubated in $3 \%(\mathrm{v} / \mathrm{v})$ hydrogen peroxide in $60 \%(\mathrm{v} / \mathrm{v})$ methanol for $20 \mathrm{~min}$ after deparaffinization. Non-specific antibody binding was minimized by treatment with either $10 \%$ normal goat serum (for anti-bPRP-I polyclonal antibody; anti-bPRP-I) or $2 \%$ (w/v) BSA (for anti-bPL monoclonal antibody; anti-bPL) for $20 \mathrm{~min}$. Sections were incubated overnight at $4^{\circ} \mathrm{C}$ with either 1:6000 anti-bPRP-I (Zieler et al., 1990) or 1:5000 anti-bPL (Takahashi et al., 2001). After washing, the sections were incubated with either biotinylated anti-rabbit (for anti-bPRP-I) or biotinylated anti-mouse IgG (for antibPL) as a secondary antibody for $60 \mathrm{~min}$. After rinsing, the sections were incubated in avidin-peroxidase complex for $30 \mathrm{~min}$ and treated with the substrate solution $(0.02 \%(\mathrm{w} / \mathrm{v})$ 3',3-diaminobenzidine tetrahydrochloride in $50 \mathrm{mmol}$ Tris buffer $\mathrm{I}^{-1}$ with $\left.0.01 \%(\mathrm{v} / \mathrm{v}) \mathrm{H}_{2} \mathrm{O}_{2}, \mathrm{pH} 7.4\right)$ for 5-10 min at room temperature. After staining by Meyer's haematoxylin for $5 \mathrm{~min}$, the sections were dehydrated and mounted in canada balsam (Wako, Osaka). Tissues were assessed using a photomicroscope (ECLIPSE E800; Nikon, Tokyo). Control sections were treated with normal rabbit IgG (for antibPRP-I) or normal mouse IgG (for anti-bPL) (diluted to $1: 200)$ instead of the antibody. The specificity of both antibodies was demonstrated (Fig. 1d-g). Other sections were stained with periodic acid-Schiff (PAS) reagent for
$15 \mathrm{~min}$ followed by Meyer's haematoxylin for $5 \mathrm{~min}$ for histological examination.

Some sections were used to detect expression of bPRP-I and bPL simultaneously using the immunofluorescence double-staining method. These sections were treated with PBS containing both $10 \%$ normal goat serum and $2 \%(\mathrm{w} / \mathrm{v})$ BSA for 20 min as blocking non-specific antibody binding. The sections were incubated with PBS solution mixed with anti-bPRP-I (diluted to 1:1000) and anti-bPL (diluted to $1: 1000)$ overnight at $4^{\circ} \mathrm{C}$. After washing, these sections were incubated with PBS solution containing both Texas Redconjugated anti-rabbit antibody (diluted to $1: 200$ ) and fluorescein isothiocyanate-conjugated anti-mouse antibody (diluted to $1: 200$ ) for $60 \mathrm{~min}$ at room temperature. After rinsing in PBS, the sections were mounted in Vectashield mounting medium (Vector Laboratories, Burlingame, CA). Tissues were assessed using a photomicroscope (ECLIPSE E800; Nikon) equipped with an epifluorescence illuminating system (HB-10103AF; Nikon). Photomicrographs were taken with Fuji Provia (Fuji, Tokyo) ISO1600 colour reversal film, using the same exposure times. Three different types of control were used for detecting background: one section was treated with anti-bPRP-I (diluted to 1:1000) and normal mouse IgG; a second section was incubated with normal rabbit IgG (diluted to 1:200) and anti-bPL (diluted to $1: 1000) ;$ and a third section was incubated with normal mouse IgG (diluted to 1:200) and normal rabbit IgG (diluted to $1: 200$ ) instead of the antibodies (Wessendorf et al., 1990). The number of binucleate cells was counted for analysing the distribution of positive cells.

\section{In situ hybridization analysis}

bPRP-I and bPL mRNAs were localized with digoxigenin (DIG)-labelled single strand cRNA probes, prepared using a DIG RNA labelling kit (Roche Molecular Biochemicals, Basel) according to the manufacturer's instructions. In brief, the cDNA fragments of bPRP-I (Gene Bank No. J02944; Schuler and Hurley, 1987) and bPL (Gene Bank No. J02840; Schuler et al., 1988) were subcloned into the HindIII-EcoRI sites of the PSPT 18 vector. The resulting plasmid was either linearized with HindIII followed by transcription with T7 RNA polymerase to generate the antisense probe, or linearized with EcoRI followed by transcription with SP6 or T3 RNA polymerase to generate the sense probe (Kizaki et al., 2001). DIG-labelled $\beta$-actin cRNA probe was prepared as a control with the same procedure. Paraffin wax sections were treated with $0.01 \%$ $(\mathrm{w} / \mathrm{v})$ proteinase $\mathrm{K}$ and $1 \mathrm{mmol}$ EDTA in $10 \mathrm{mmol}$ Tris- $\mathrm{HCl}$ $\mathrm{I}^{-1}(\mathrm{pH} 7.4)$ for $30 \mathrm{~min}$ at $37^{\circ} \mathrm{C}$. After post-fixation by $4 \%$ $(\mathrm{w} / \mathrm{v})$ paraformaldehyde in $\mathrm{PBS}$, these sections were treated in $0.2 \mathrm{~mol} \mathrm{HCl} \mathrm{I}^{-1}$. After washing in PBS, the sections were dehydrated in alcohol and air-dried. Prehybridization was performed in a $100 \mu \mathrm{l}$ droplet of prehybridization buffer $\left(50 \% \quad(\mathrm{v} / \mathrm{v})\right.$ formamide, $1 \mathrm{mg}$ tRNA ml $\mathrm{m}^{-1}, 2 \times$ Denhart's $^{\prime}$ solution and $10 \times \mathrm{SSC}$ ). After $120 \mathrm{~min}$ at room temperature, the sections were incubated with $2 \mathrm{ng} \mathrm{ml}^{-1}$ 

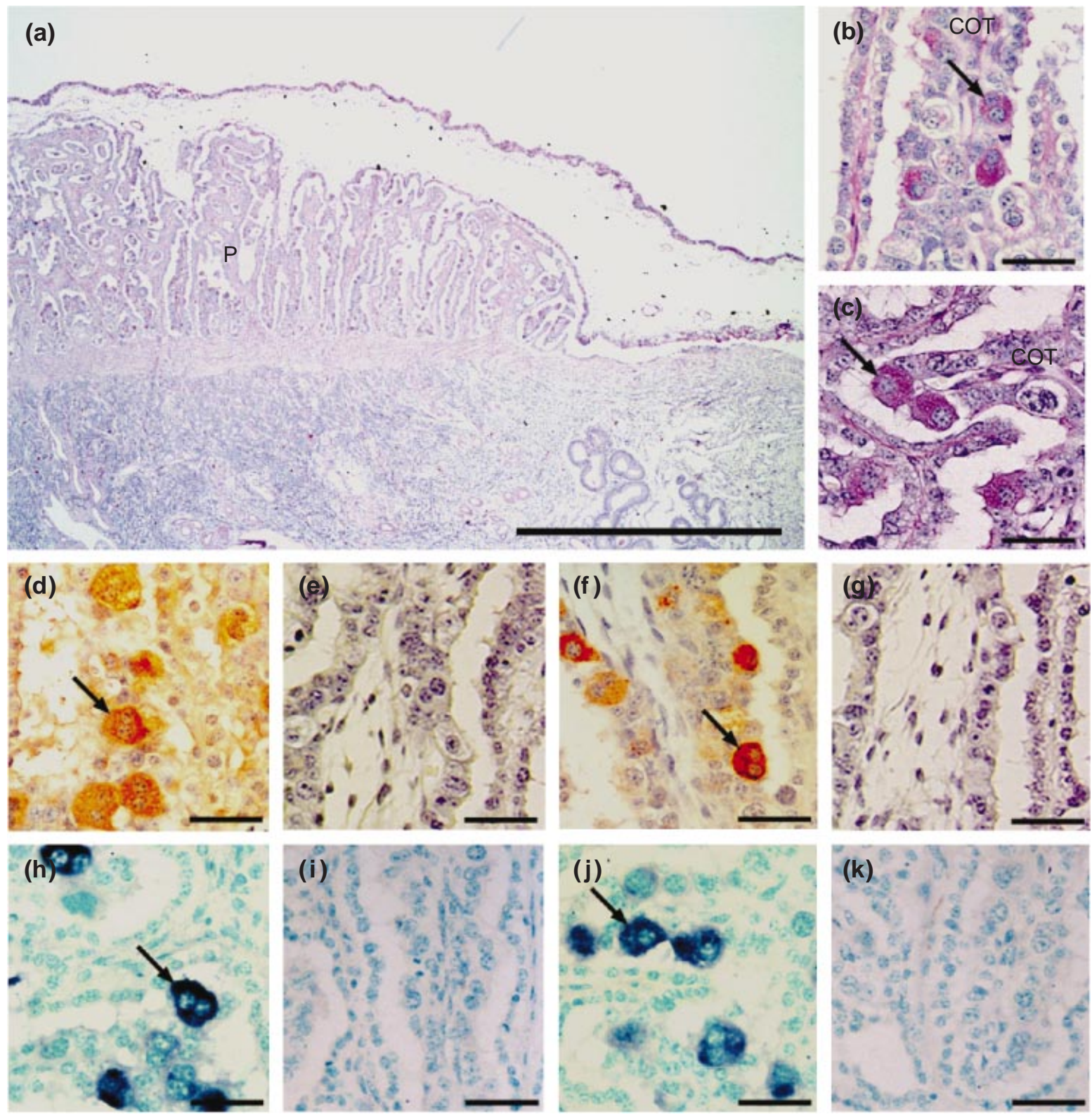

Fig. 1. Bovine fetal trophoblast and uterine endometrium on day 60 of gestation. (a) Placentome (P) stained with periodic acid-Schiff (PAS). (b,c) Binucleate cell in fetal cotyledon (COT) stained with PAS. (d) Immunohistochemical staining of bovine prolactin-related protein I (bPRP-I). (e) Normal rabbit IgG. (f) Immunohistochemical staining of bovine placental lactogen (bPL). (g) Normal mouse IgG. (h) In situ detection of bPRP-I mRNA. (i) bPRP-I sense probe. (j) In situ detection of bPL mRNA. (k) bPL sense probe. Arrows indicate binucleate cells. Scale bars represent (a) $1 \mathrm{~mm}$ and (b-k) $50 \mu \mathrm{m}$.

DIG-labelled antisense or sense specific probe of bPRP-I or bPL in hybridization buffer for $16-18 \mathrm{~h}$ at $45-50^{\circ} \mathrm{C}$. Hybridization buffer consisted of $50 \%(\mathrm{v} / \mathrm{v})$ formamide, $0.2 \mathrm{mg}(\mathrm{w} / \mathrm{v})$ tRNA $\mathrm{ml}^{-1}, 1 \times$ Denhardt's solution, $10 \%(\mathrm{v} / \mathrm{v})$ dextran sulphate, $0.2 \%(\mathrm{w} / \mathrm{v})$ SDS, 1 mmol EDTA $\mathrm{I}^{-1}$ and 600 mmol $\mathrm{NaCl} \mathrm{I}^{-1}$ in 10 mmol Tris-HCl ${ }^{-1}$ (pH 7.6). After hybridization, the sections were rinsed in $2 \times \mathrm{SSC} / 50 \%$ $(\mathrm{v} / \mathrm{v})$ formamide for $30 \mathrm{~min}$ at $60^{\circ} \mathrm{C}$ and treated with $10 \mu \mathrm{g}$

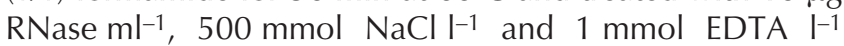
in $10 \mathrm{mmol}$ Tris- $\mathrm{HCl} \mathrm{I}^{-1}(\mathrm{pH}$ 7.6). After rinses in $2 \times$ and
$0.2 \times$ SSC for $20 \mathrm{~min}$ each at $42^{\circ} \mathrm{C}$, the sections were incubated with $1.5 \%(\mathrm{w} / \mathrm{v})$ blocking reagent (Roche Molecular Biochemicals) in 100 mmol Tris- $\mathrm{HCl} \mathrm{l}^{-1}(\mathrm{pH} 7.6)$ with $150 \mathrm{mmol} \mathrm{NaCl} \mathrm{l-1}$ (TBS) for $60 \mathrm{~min}$ at room temperature and $0.3 \%(\mathrm{v} / \mathrm{v})$ Triton-X100 in TBS including anti-DIG-alkaline phosphate Fab fragments (diluted 1:2000) (Boehringer Mannheim, Mannheim) overnight at $4^{\circ} \mathrm{C}$. After washing with $0.3 \%(\mathrm{v} / \mathrm{v})$ Triton-X100 in TBS, the sections were treated in $100 \mathrm{mmol}$ Tris- $\mathrm{HCl} \mathrm{l} \mathrm{I}^{-1}(\mathrm{pH}$ 9.4) with NBT/BCIP kit (Vector Laboratories) for 16-24 h at room 

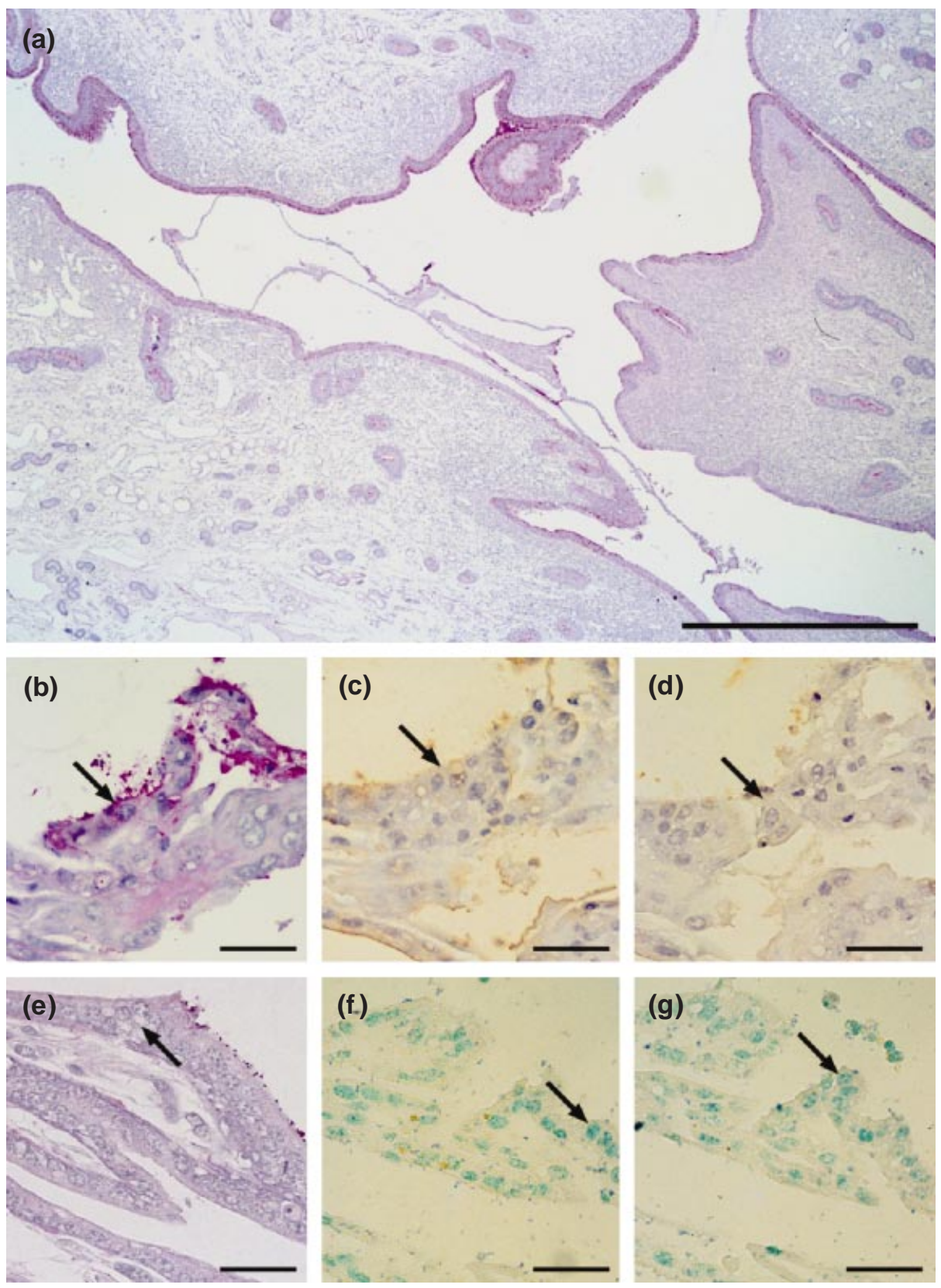

Fig. 2. Interface between bovine fetal trophoblast and uterine endometrium on day 19 of gestation. (a) Elongated trophoblast in the uterine lumen stained with periodic acid-Schiff (PAS). (b) Binucleate cell in fetal trophoblast stained with PAS. (c) Immunohistochemical staining of bovine prolactin-related protein I (bPRP-I). (d) Immunohistochemical staining of bovine placental lactogen (bPL). (e) Binucleate cell in fetal trophoblast stained with PAS. (f) In situ detection of bPRP-I mRNA. (g) In situ detection of bPL mRNA. Arrows indicate binucleate cells. Scale bars represent (a) $1 \mathrm{~mm}$ and (b-g) $50 \mu \mathrm{m}$.

temperature. After staining with $1 \%(\mathrm{w} / \mathrm{v})$ methyl green, the sections were dehydrated and mounted in canada balsam. Some sections were treated with $\beta$-actin antisense probe instead of the hybridization buffer as a control. The specificity of DIG-labelled probes was demonstrated (Fig. $1 \mathrm{~h}-\mathrm{k})$.

\section{Northern blot hybridization}

Total RNA was extracted from placental tissues using ISOGEN (Nippon Gene, Toyama) according to the manufacturer's instructions and northern blot hybridization was performed as described by Kizaki et al. (2001). In brief, 

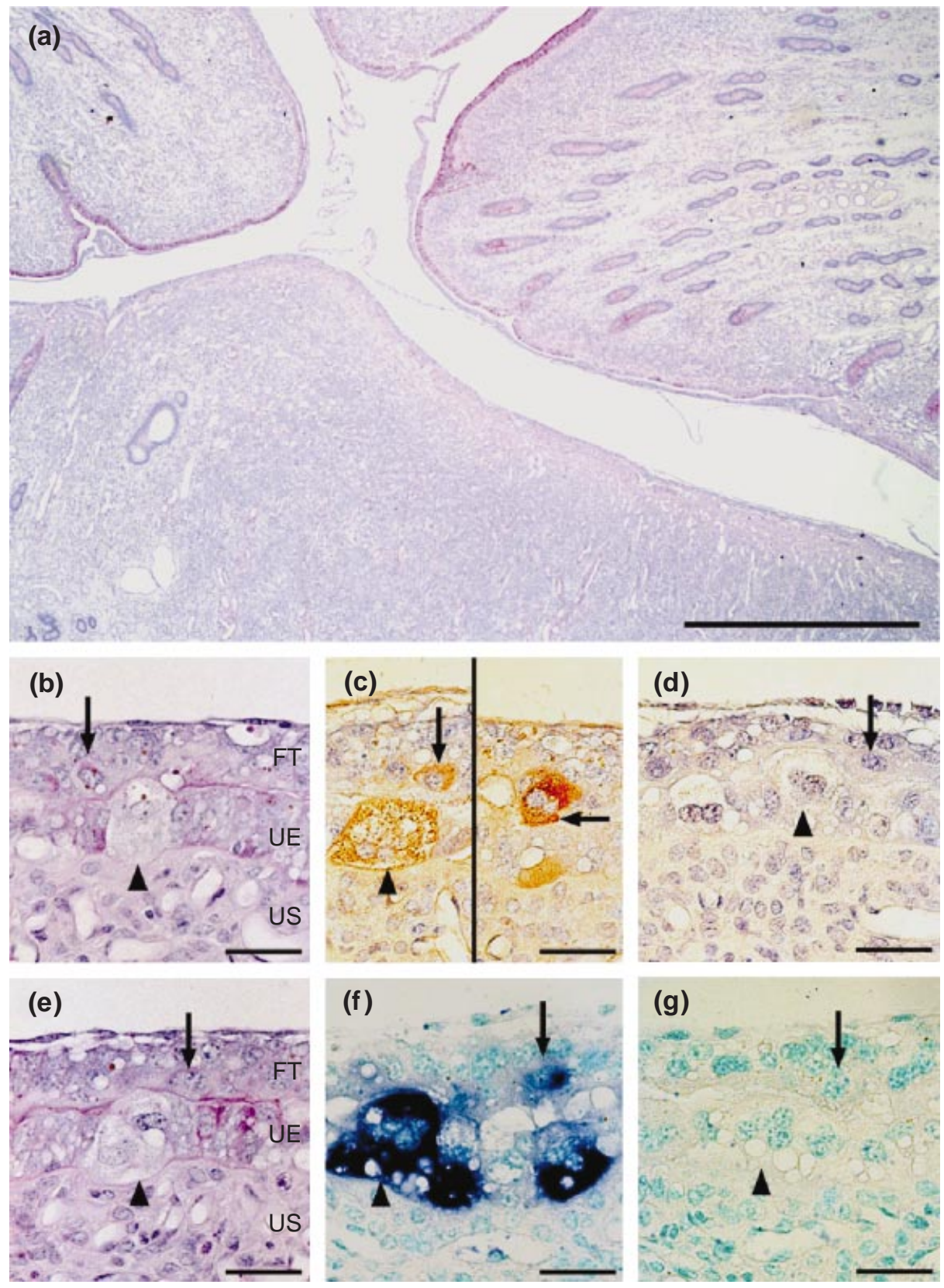

Fig. 3. Bovine fetal trophoblast and uterine endometrium on day 20 of gestation. (a) Fetal trophoblast stained with periodic acid-Schiff (PAS). (b) Binucleate cell and multinuclear cells in fetomaternal interface stained with PAS. (c) Immunohistochemical staining of bovine prolactinrelated protein I (bPRP-I) in a binucleate cell (right) and a multinuclear cell (left). (d) Immunohistochemical staining of bovine placental lactogen (bPL). (e) Binucleate cell and multinuclear cells in fetomaternal interface stained with PAS. (f) In situ detection of bPRP-I mRNA. (g) In situ detection of bPL mRNA. FT: fetal trophoblast; UE: uterine epithelium; US: uterine stroma; arrows: binucleate cells; arrowheads: multinuclear cells. Scale bars represent (a) $1 \mathrm{~mm}$ and (b-g) $50 \mu \mathrm{m}$.

total RNA $(10 \mu \mathrm{g})$ derived from the conceptus on day 17 and the cotyledons on days 30 and 60 of gestation (day 17, $n=1$; day $30, n=3$; day $60, n=3$ ) was fractionated on a $1.2 \%(\mathrm{w} / \mathrm{v})$ agarose-formaldehyde gel. RNA was transferred overnight by capillary action in $20 \times$ SSC on to a positively charged nylon filter (Boehringer Mannheim) and immobilized by UV irradiation. After prehybridization for $1 \mathrm{~h}$ in hybridization buffer consisting of $50 \%(\mathrm{v} / \mathrm{v})$ formamide, $5 \times \mathrm{SSC}, 2 \%(\mathrm{w} / \mathrm{v})$ blocking regent, $0.1 \mathrm{mg}$ tRNA $\mathrm{ml}^{-1}, 0.1 \%(\mathrm{v} / \mathrm{v}) \mathrm{N}$-lauroyl sarcosine and $0.1 \%(\mathrm{w} / \mathrm{v})$ 

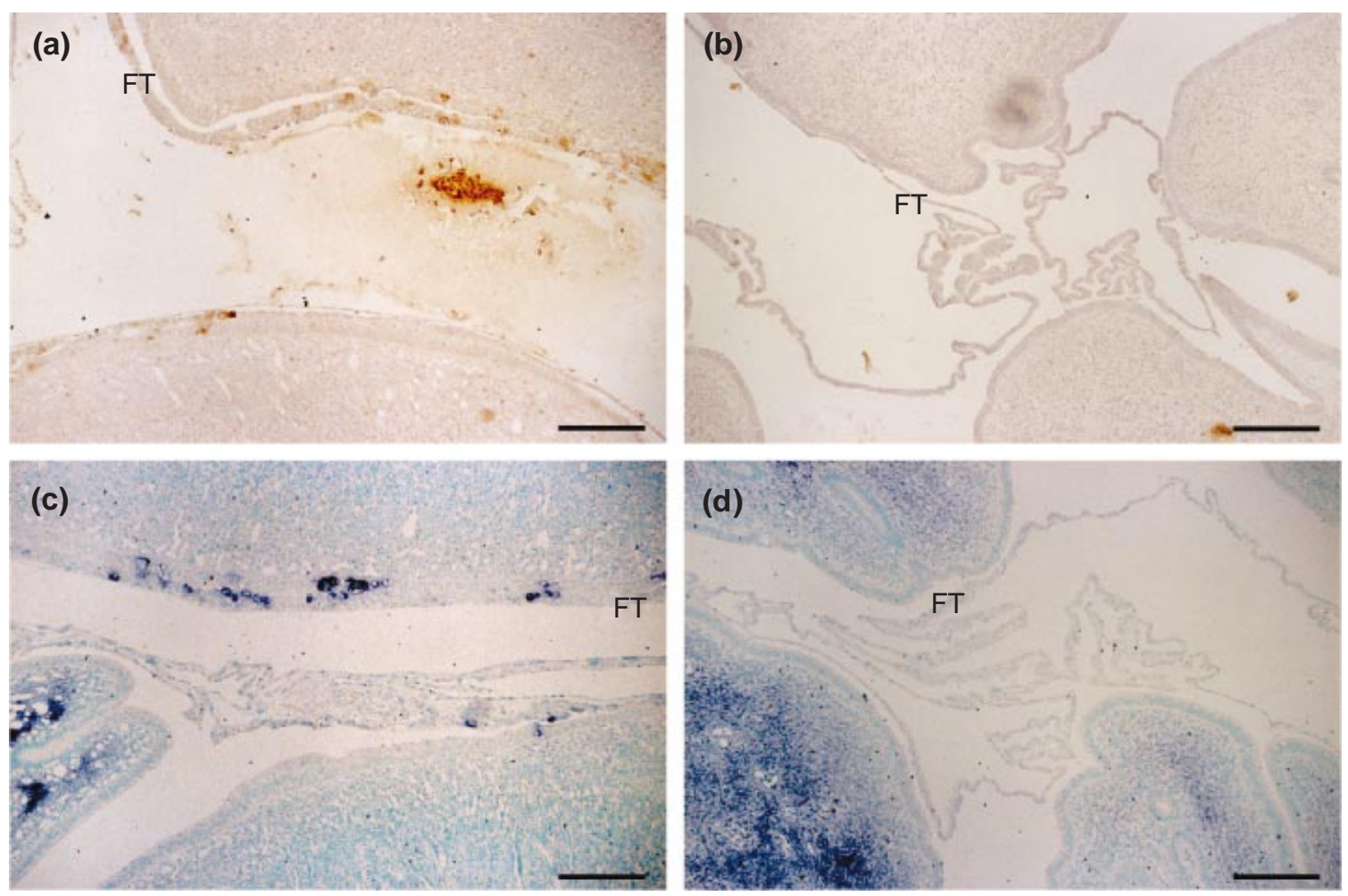

Fig. 4. Specific localization of bovine prolactin-related protein I (bPRP-I)-expressing cells in (a,c) gravid and (b,d) nongravid uterine horns on day 20 of gestation. (a,b) Immunohistochemical staining for bPRP-I. (c,d) In situ detection of bPRP-I mRNA. FT: fetal trophoblast. Scale bars represent $200 \mu \mathrm{m}$.

SDS, hybridization was performed with the same specific probes as for in situ hybridization analysis at $68^{\circ} \mathrm{C}$ overnight. The filter was washed sequentially twice with $2 \times$ SSC containing $0.1 \%(\mathrm{w} / \mathrm{v})$ SDS for $15 \mathrm{~min}$ at room temperature, and in $0.1 \times$ SSC containing $0.1 \%(\mathrm{w} / \mathrm{v}) \mathrm{SDS}$ for $30 \mathrm{~min}$ at $68^{\circ} \mathrm{C}$. The filter was incubated for $1 \mathrm{~h}$ in $0.1 \mathrm{~mol}$ maleic acid $\mathrm{l}^{-1}$ and $0.15 \mathrm{~mol} \mathrm{NaCl}^{-1}$ containing $1 \%$ $(\mathrm{w} / \mathrm{v})$ blocking reagent (blocking buffer), and incubated further in anti-DIG-alkaline phosphate Fab fragments (diluted 1:10000) in blocking buffer. After incubation, the filter was washed three times with 0.1 mol maleic acid $\mathrm{I}^{-1}$ and $0.15 \mathrm{~mol} \mathrm{NaCl}^{-1}$ containing $0.3 \%(\mathrm{v} / \mathrm{v})$ Tween 20 for $15 \mathrm{~min}$ at room temperature followed by $5 \mathrm{~min}$ of rinsing in $100 \mathrm{mmol}$ Tris- $\mathrm{HCl} \mathrm{I}^{-1}(\mathrm{pH}$ 9.5) containing $150 \mathrm{mmol}$ $\mathrm{NaCl} \mathrm{I-1}$ and $50 \mathrm{mmol} \mathrm{MgCl}_{2} \mathrm{I}^{-1}$. For signal detection, the filter was incubated for $5 \mathrm{~min}$ in $0.25 \mathrm{mmol}$ CDP-star ${ }^{\circledR}$ (TROPIX, Bedford, MA) ${ }^{-1}$ as a chemiluminescent substrate and was exposed to Kodak XAR-5 film for 1-20 min. Signals were analysed using $\mathrm{NIH}$ image (1.62f) and were normalized to the expression of $\beta$-actin measured in the same RNA preparation.

\section{Results}

\section{Preimplantation period (days 17-19 of gestation)}

Elongated trophoblast and fetus were found in the lumen of only the gravid uterine horn. At this time, the trophoblastic membrane was attached to uterine endometrium but the trophoblast cells had not yet fused with the epithelial cells (Fig. 2a). Cuboidal trophoblastic cells near the embryo had a large round single nucleus and a few cells contained faintly staining cytoplasmic PASpositive granules (Fig. 2b,e). Other trophoblastic cells were PAS negative (Fig. 2b,e). Uterine epithelial cells stained strongly with PAS (Fig. 2a). No bPRP-I immunoreactivity was detectable in any trophoblastic cells at this time (Fig. 2c) and no bPRP-I mRNA was found (Fig. 2f). Similarly, neither bPL protein nor mRNA could be detected (Fig. 2d,g).

\section{Implantation period (days 20-25 of gestation)}

Embryonic trophoblastic membrane was found in the uterine lumen of both gravid and non-gravid horns. Initiation of placental formation (implantation) was found in many places on the endometrium (Fig. 3a). In the gravid horn, the cytotrophoblast, which was composed of mononucleate and binucleate cells, was closely apposed to the uterine endometrial epithelium, which stained with PAS (Fig. 3b,e). The cytoplasm of binucleate cells contained immunoreactive bPRP-I (Fig. 3c). However, bPL could not be detected (Fig. 3d). Similarly, in situ hybridization detected bPRP-I mRNA, but not bPL mRNA (Fig. 3f,g). In addition, the binucleate cell, which contained immunoreactive bPRP-I, extended cytoplasmic projections 

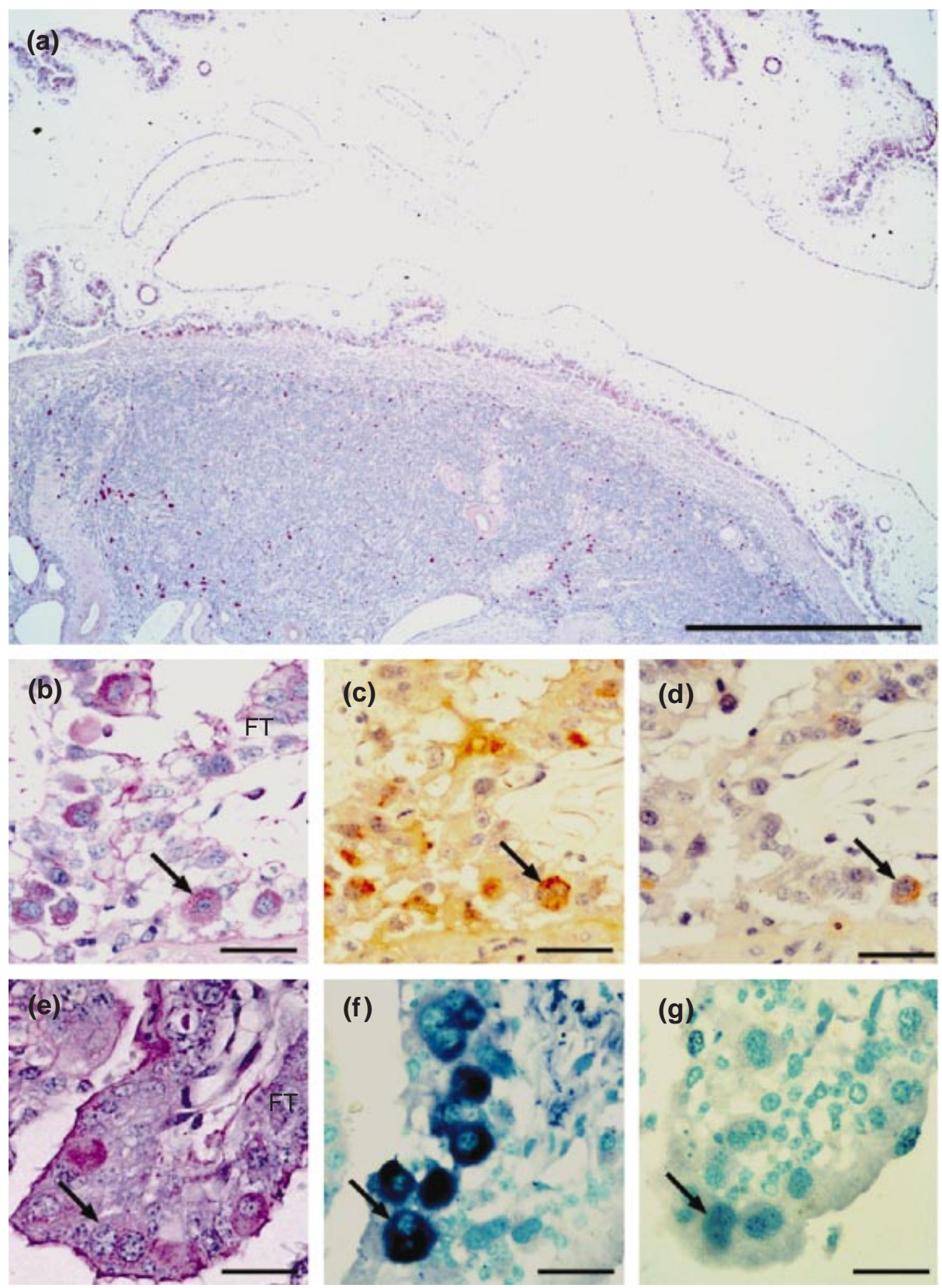

Fig. 5. Bovine fetal trophoblast and uterine endometrium on day 30 of gestation. (a) Developed trophoblast and uterine endometrium stained with periodic acid-Schiff (PAS). (b) Binucleate cell in fetal trophoblast (FT) stained with PAS. (c) Immunohistochemical staining of bovine prolactinrelated protein I (bPRP-I). (d) Immunohistochemical staining of bovine placental lactogen (bPL). (e) Binucleate cell in fetal trophoblast with PAS staining. (f) In situ detection of bPRP-I mRNA. (g) In situ detection of bPL mRNA. Arrows indicate binucleate cells. Scale bars represent (a) $1 \mathrm{~mm}$ and (b-g) $50 \mu \mathrm{m}$.

to the uterine epithelium (left of Fig. 3c). In the implantation area, many multinuclear cells were found in the uterine epithelium (Fig. 3b,e). The multinuclear cells were scattered in both the caruncular and intercaruncular epithelium of the gravid horn, and were closely apposed to the uterine stroma as well as the implanting trophoblastic membrane (compare Fig. 4a,b). These multinuclear cells had PASpositive and anti-bPRP-I immunoreactive granules (Fig. 3b,c), and expressed bPRP-I mRNA (Fig. 3f). However, bPL protein and mRNA were not found in these cells (Fig. 3d,g). In the non-gravid horn, the elongated trophoblastic membrane was attached intermittently to the uterine 

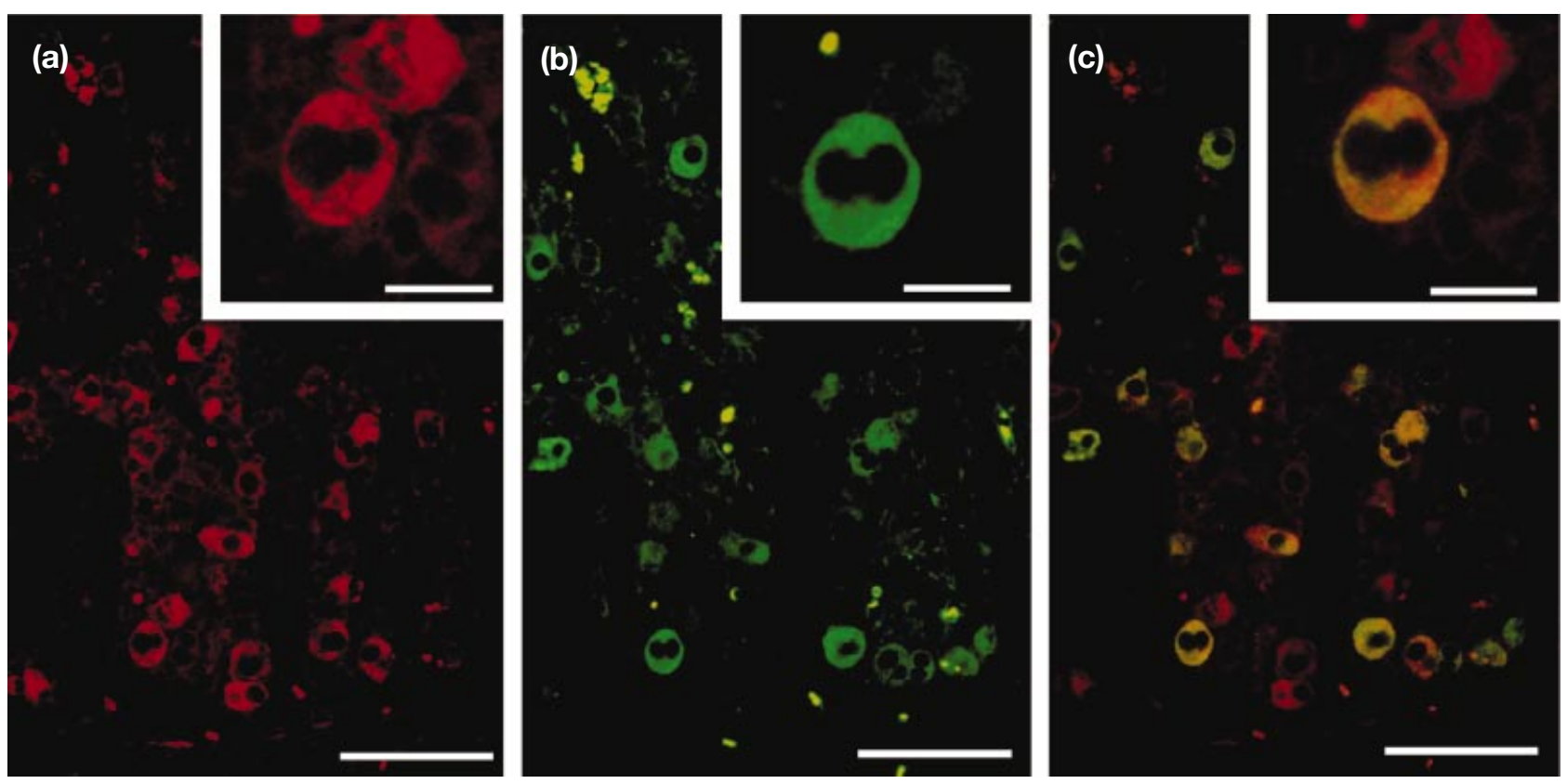

Fig. 6. Detection of bovine prolactin-related protein I (bPRP-I) and bovine placental lactogen (bPL) in fetal binucleate cells by double fluorescence staining. (a) Immunoreactive PRP-I in binucleate cells. (b) Immunoreactive bPL in binucleate cells. (c) Co-expression of bPRP-I and bPL in binucleate cells. Scale bars represent $(\mathrm{a}-\mathrm{c}) 100 \mu \mathrm{m}$ and $50 \mu \mathrm{m}$ in insets.

endometrium and contained primarily mononucleate cells, with a few binucleate cells. However, bPRP-I protein and mRNA were not detected in the non-gravid horn (compare Fig. 4a,d). In addition, multinuclear cells, which were common in the gravid horn, were not found in the uterine epithelium of the non-gravid horn (Fig. 4a-d).

\section{Post-implantation period (days 26-30 of gestation)}

During this period, placental formations (cotyledons) were consistently found in the gravid horn, especially near the fetus (Fig. 5a). Chorionic villi were well developed in these structures and contained many binucleate cells strongly stained with PAS (Fig. 5b,e). These binucleate cells showed immunoreactivity with both anti-bPRP-I and antibPL, and expressed bPRP-I as well as bPL mRNA (Fig. $5 c, d, f, g)$. However, binucleate cells contained apparently higher amounts of bPRP-I than bPL.

\section{Placentation (about day 60 of gestation)}

During this period, well-developed placentomes were found in both gravid and non-gravid horns (Fig. 1a). These placentomes had many mononucleate cells and binucleate cells in the cotyledons (Fig. 1b,c). The binucleate cells, which contained PAS-positive granules (Fig. 1b,c), contained immunoreactive bPRP-I and bPL (Fig. 1d,f), as well as both bPRP-I and bPL mRNA (Fig. 1h,j). Expression of both proteins was confirmed using immunofluorescence double staining and it was found that some expressed bPRP$\mathrm{I}$ and bPL simultaneously (Fig. 6a-c). In total, 734 binucleate cells were counted and more than half of them $(440,60 \%)$ expressed both bPRP-I and bPL. Of the other half, $10 \%$ were positive for bPRP-I only, $25 \%$ were positive for bPL only and $5 \%$ were negative for both.

\section{Northern blot analysis of bPRP-I and bPL $m R N A$}

No transcripts were detectable for either bPRP-I or bPL on day 17 of gestation. However, by day 30, transcripts were readily detected for both proteins. Amounts of bPRP-I mRNA were approximately tenfold higher than those for bPL $(n=3, P<0.01)$. By day 60 , the relative bPL expression was about fivefold greater than at day 30 , but was still lower than that of bPRP-I $(n=3, P<0.01)$ at this stage (Fig. 7a,b). These quantitative data paralleled that of in situ hybridization and immunohistochemical analyses.

\section{Discussion}

The prolactin/GH family performs multiple functions during fetal and adult life. The uteroplacental unit produces members of this family in many species including cows, mice and rats, as well as primates (Anthony et al., 1995; Rasmussen et al., 1996; Soares et al., 1998; Müller et al., 1999). The structure of these hormones differs considerably across species. The bovine placenta produces at least two PLs and six PRPs (Schuler and Kessler, 1992; Anthony et al., 1995). bPRP-I is the only member of the non-classical prolactin family that has been shown to be translated other than bPL (Schuler and Hurley, 1987; Zieler et al., 1990). 
(a)

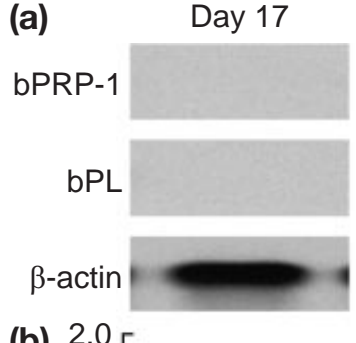

(b) 2.0

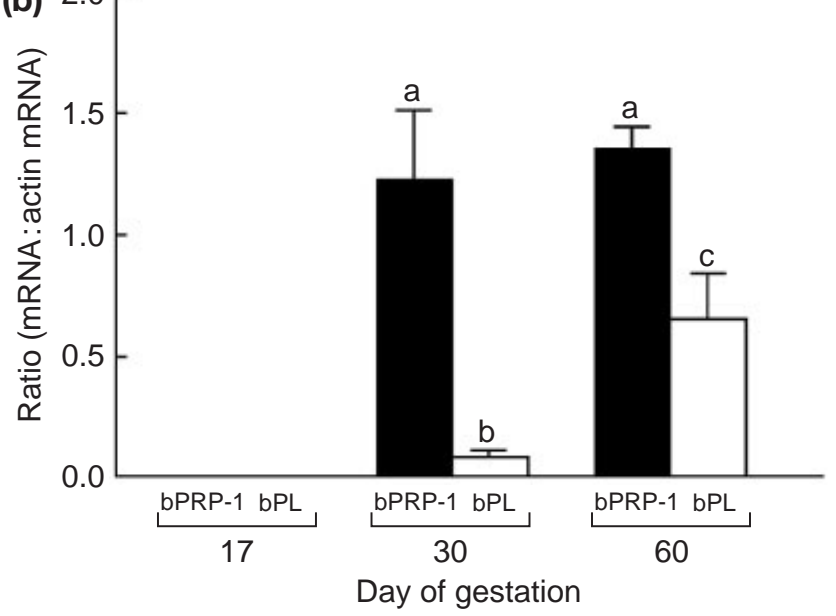

Fig. 7. Expression of bovine prolactin-related protein I (bPRP-I) and bovine placental lactogen (bPL) mRNA on days 17, 30 and 60 of gestation. (a) Northern blot analysis of bPRP-I and bPL transcripts. (b) Signals were quantified using NIH image and arbitrary values $($ mean \pm SD) and were corrected for RNA loading based on the value obtained for $\beta$-actin in the same lane. Three separate samples were evaluated from day 30 and day 60 of gestation, respectively; a single sample from day 17 was examined. ${ }^{a-c}$ Values with different letters are significantly different $(P<0.01)$.

bPRP-I is a glycoprotein, modified by heterogeneous $\mathrm{N}$ glycosylation of an apparently single polypeptide, resulting in a doublet of apparent molecular weight of 34000 (Zieler et al., 1990). bPRP-I is quite distinct from bovine prolactin (43\% amino acid sequence similarity; $63 \%$ nucleic acid sequence similarity), is less closely related to prolactin than bPL and does not bind to prolactin receptors (Kessler et al., 1989; Schuler et al., 1991). The production of both bPRP-I and bPL early in pregnancy by the binucleate cells has been demonstrated (Milosavljevic et al., 1989; Kessler et al., 1991), although the initiation of expression was not defined in these studies. Recently, bPRP-I was purified and found in uterine fluid of pregnant cows, consistent with local effects (Kessler and Schuler, 1997).

Binucleate cells first appear just before implantation in the cytotrophoblast layer of the ruminant trophoblast (Wooding, 1992). During implantation, the elongating cytotrophoblastic cells begin to contact the epithelial cells at about day 17 , and maternal and fetal cells fuse together at about days 20-21 of gestation. The function of the resulting multinuclear cells and binucleate cells is not understood (King et al., 1980; Wooding, 1992). In the present study, it was found that binucleate cells as well as multinuclear cells at the interface of the fetal trophoblast and maternal epithelium express bPRP-I protein and mRNA on day 20 of gestation. This early expression of bPRP-I may be indicative of a role in the marked morphological and functional changes that occur in the maternal endometrium and fetal trophoblast during early gestation. Moreover, the production of bPRP-I during early implantation, and secretion into the uterine fluid and serum of pregnant cows (Kessler and Schuler, 1997), indicate that it may be a good candidate for pregnancy diagnosis.

The specific function or functions of the placental prolactin family, including bPRP-I and bPL, during implantation in cows is not clear. However, specific binding sites for bPL have been identified in uterine endometrium throughout pregnancy, as well as during the luteal phase of the oestrous cycle (Galosy et al., 1991; Kessler et al., 1991), although molecular characterization of a unique receptor for this molecule has not been reported (Anthony et al., 1995). bPRP-I does not bind to these binding sites, or to $\mathrm{GH}$ or prolactin receptors. On the basis of its affinity for alpha 2-macroglobulin, bPRP-I has been postulated to perform paracrine actions at the fetomaternal interface (Kessler and Schuler, 1997). In other species, functions have been identified for several placental prolactin-related hormones, although differences among these hormones as well as placental anatomy make it difficult to extrapolate across species. In humans, the implantation site demonstrates a localized increase in prolactin and insulin-like growth factor binding protein 1 (Brar et al., 1995). Decidual prolactin-related protein in the rat binds to a heparin sulphate proteoglycan and may be involved in the control of uterine blood vessel development (Rasmussen et al., 1996). Rat prolactin-like protein A interacts with natural killer cells in the mesometrial compartment of the pregnant uterus (Müller et al., 1999). These reports establish several roles for these hormones in fetomaternal interaction during the implantation period in rodents and humans. In ruminants, modifications in the endometrium necessary for successful implantation and placentation have been described: immunosuppression for preventing rejection of the fetal allograft, remodelling of extracellular matrix and angiogenesis (Reynolds and Redmer, 1992; Weitlauf, 1994; Guillomot, 1999). Although additional studies are necessary, the temporal and spatial distribution of bPRP-I expression shown in the present study indicates that bPRP-I may have a function in fetomaternal interactions during the implantation period in cows, similar to other members of the prolactin/GH family in other species.

Large multinuclear cells appear in the uterine epithelium during days 20-29 of gestation as a result of trophoblast cell migration into the endometrium or fusion with the epithelium (King et al., 1980; Wooding, 1992; Wooding and Flint, 1994; Klisch et al., 1999a). Tri- and multinucleate cells at the fetomaternal interface contain granules of various sizes that immunostain for bPL as well as other 
placenta-specific molecules (Wooding and Beckers, 1987; Morgan et al., 1989). These cells degenerate after exocytosis of these granules (Bjorkman, 1968, 1969; Wooding, 1992; Klisch et al., 1999a). However, in the present study, some multinuclear cells were found in the endometrium close to fetal trophoblastic cells, indicating that they might be composed of only endometrial cells. In the present study, not only binucleate cells but also these multinuclear cells produced bPRP-I protein and mRNA. Together, these data indicate that multinuclear cells might be formed by not only the migration of fetal binucleate cells into uterine epithelium and subsequent fusion, but also fusion of endometrial cells, stimulated by factors such as bPRP-I or a related molecule from binucleate cells. Recently, Kizaki et al. (2001) demonstrated that binucleate cells express heparanase, an extracellular matrix-degrading enzyme with functions in cell migration and fusion in tumour cells, which is indicative of an important role in cell-cell or cell-matrix remodelling. However, the origin and function of the multinuclear cells remain unclear. In the present study, bPRP-I was found in binucleate cells and multinuclear cells only in trophoblastic membrane within the gravid horn at the implantation site on day 20 of gestation. This pattern of expression of bPRP-I continues throughout pregnancy, indicating that it may have a specific role in fetomaternal interaction during initiation of implantation, such as in adherence and migration of trophoblast cells, which continues throughout gestation.

In the present study it has been demonstrated that binucleate cells can simultaneously produce both bPRP-I and bPL using immunofluorescence double staining, consistent with previous results demonstrating colocalization of mRNAs (Milosavljevic et al., 1989). Bovine binucleate cells typically contain high DNA content, 4-16 nuclei, which may increase their synthetic capacity (Klisch et al., 1999b). The trophoblast giant cells of rodent placenta share some characteristics with binucleate cells: they differentiate from fetal cytotrophoblast, increase their DNA content by endo-reduplication (Barlow and Sherman, 1972) and express members of the prolactin/GH family, including PLs, prolactin-like proteins, proliferin and proliferin-related proteins (Lee et al., 1988; Faria et al., 1991; Soares et al., 1998; Ma and Linzer, 2000). Both binucleate cells in ruminants and trophoblastic giant cells in rodents also migrate and invade, although the degree of migratory activity varies among species (Hoffman and Wooding, 1993). Bovine trophoblastic mononucleate cells do not express bPRP-I and bPL (Wooding, 1992; Wooding et al., 1992; Nakano et al., 2001). Binucleate cells may be multifunctional cells that direct trophoblastic cell differentiation through various molecules such as prolactin family, pregnancy-associated glycoproteins and heparanase (Duello et al., 1986; Zoli et al., 1992; Anthony et al., 1995; Kizaki et al., 2001). The intricate interactions among the various molecules produced by binucleate cells may be required to establish placentomes.

In conclusion, bPRP-I may play a primary role in the fusion of trophoblastic cells and endometrial epithelial cells, and may be an excellent early indicator of trophoblast cell differentiation.

This work was supported by the Bio-oriented Technology Research Advancement Institution and by the Organized Research Combination System from the Science and Technology Agency, Japan.

\section{References}

Anthony RV, Liang R, Kayl EP and Pratt SL (1995) The growth hormone/prolactin gene family in ruminant placentae Journal of Reproduction and Fertility Supplement 49 83-95

Barlow PW and Sherman MI (1972) The biochemistry of differentiation of mouse trophoblast: studies on polyploidy Journal of Embryology and Experimental Morphology 27 447-465

Bjorkman NH (1968) Fine structure and cryptal and trophoblastic giant cells in the bovine placentome Journal of Ultrastructure Research $\mathbf{2 4}$ 249-258

Bjorkman NH (1969) Light and electron microscopic studies on cellular alterations in the normal bovine placentome Anatomical Record $\mathbf{1 6 3}$ $17-30$

Brar AK, Frank GR, Richards RG, Meyer AJ, Kessler CA, Cedars MI, Klein DJ and Handwerger S (1995) Laminin decreases PRL and IGFBP-1 expression during in vitro decidualization of human endometrial stromal cells Journal of Cellular Physiology 163 30-37

Duello TM, Byatt JC and Bremel RD (1986) Immunohistochemical localization of placental lactogen in binucleate cells of bovine placentomes Endocrinology 119 1351-1355

Faria TN, Ogren L, Talamantes F, Linzer DI and Soares MJ (1991) Localization of placental lactogen-I in trophoblast giant cells of the mouse placenta Biology of Reproduction 44 327-331

Galosy SS, Gertler A, Elberg G and Laird DM (1991) Distinct placental lactogen and prolactin (lactogen) receptors in bovine endometrium Molecular and Cellular Endocrinology 78 229-336

Guillomot H (1999) Changes in extracellular matrix components and cytokeratins in the endometrium during goat implantation Placenta $\mathbf{2 0}$ 339-345

Hoffman LH and Wooding FB (1993) Giant and binucleate trophoblast cells of mammals Journal of Experimental Zoology 266 559-577

Kessler MA and Schuler LA (1997) Purification and properties of placental prolactin-related protein-I Placenta 18 29-36

Kessler MA, Milosavljevic M, Zieler CG and Schuler LA (1989) A subfamily of bovine prolactin-related transcripts distinct from placental lactogen in fetal placenta Biochemistry 28 5154-5161

Kessler MA, Duello TM and Schuler LA (1991) Expression of prolactinrelated hormones in the early bovine conceptus and potential for paracrine effect on the endometrium Endocrinology 129 1885-1895

King GJ, Atkinson BA and Robertson HA (1980) Development of the bovine placentome from days 20 to 29 of gestation Journal of Reproduction and Fertility 59 95-100

Kizaki K, Nakano H, Nakano H, Takahashi T, Imai K and Hashizume K (2001) Expression of heparanase mRNA in bovine placenta during gestation Reproduction 121 573-580

Klisch K, Pfarrer C, Schuler G, Hoffmann B and Leiser R (1999a) Tripolar acytokinetic mitosis and formation of feto-maternal syncytia in the bovine placentome: different modes of generation of multinuclear cells Anatomy and Embryology 200 229-237

Klisch K, Hecht W, Pfarrer C, Schuler G, Hoffmann B and Leiser R (1999b) DNA content and ploidy level of bovine placentomal trophoblast giant cells Placenta 20 451-458

Lee SJ, Talamantes F, Wilder E, Linzer DIH and Nathans D (1988) Trophoblastic giant cells of the mouse placenta as the site of proliferin synthesis Endocrinology 122 1761-1768

Ma GT and Linzer DIH (2000) GATA-2 restricts prolactin-like protein A expression to secondary trophoblast giant cells in the mouse Biology of Reproduction 63 570-574 
Milosavljevic M, Duello TM and Schuler LA (1989) In situ localization of two prolactin-related messenger ribonucleic acids to binucleate cells of bovine placentomes Endocrinology 125 883-889

Morgan G, Wooding FBP, Beckers JF and Friesen HG (1989) An immunological cryo-ultrastructural study of a sequential appearance of proteins in placental binucleate cells in early pregnancy in the cow Journal of Reproduction and Fertility 86 745-752

Müller H, Liu B, Croy BA, Head JR, Hunt JS, Dai G and Soares MJ (1999) Uterine natural killer cells are targets for a trophoblast cell-specific cytokine, prolactin-like protein A Endocrinology 140 2711-2720

Murthy GS, Schellenberg C and Friesen HG (1982) Purification and characterization of bovine placental lactogen Endocrinology $\mathbf{6 8}$ 141-146

Nakano H, Takahashi T, Imai K and Hashizume K (2001) Expression of placental lactogen and cytokeratin in bovine placental binucleate cells in culture Cell and Tissue Research 303 263-270

Rasmussen CA, Hashizume K, Orwig KE, Xu L and Soares MJ (1996) Decidual prolactin-related protein: heterologous expression and characterization Biology of Reproduction 137 5558-5566

Reynolds LP and Redmer DA (1992) Growth and microvascular development of the uterus during early pregnancy in ewe Biology of Reproduction 47 698-708

Schuler LA and Hurley WL (1987) Molecular cloning of a prolactin-related mRNA expressed in bovine placenta Proceedings National Academy of Sciences USA 84 5650-5654

Schuler LA and Kessler MA (1992) Bovine placental prolactin-related hormones Trends in Endocrinology and Metabolism 3 334-338

Schuler LA, Shimomura K, Kessler MA, Zieler CG and Bremel RD (1988) Bovine placental lactogen: molecular cloning and protein structure Biochemistry 27 8443-8448

Schuler LA, Kessler MA, Tanaka M and Nakashima K (1991) Nomenclature clarification for the bovine placental prolactin-related hormones Endocrinology 1292057

Soares MJ, Müller H, Orwig KE, Peters TJ and Dai G (1998) The uteroplacental prolactin family and pregnancy Biology of Reproduction $58273-284$

Takahashi T, Aso H and Hashizume K (2001) Immunological and biological activities of bovine placental lactogen in placental explant culture Journal of Reproduction and Development 47 63-67

Tanaka M, Minoura H, Ushiro H and Nakashima K (1991) A novel cDNA clone encoding a prolactin-like protein that lacks the two C-terminal cysteine residues isolated from bovine placenta Biochimica et Biophysica Acta 1088 385-389

Weitlauf HM (1994) Biology of implantation. In The Physiology of Reproduction pp 391-440 Eds E Knobil and JD Neill. Raven Press, New York

Wessendorf MW, Appel NM, Molitor TW and Elde RP (1990) A method for immunofluorescent demonstration of three coexisting neurotransmitters in rat brain and spinal cord, using the fluorophores fluorescein, lissamine rhodamine, and 7-amino-4-methylcoumarin-3-acetic acid Journal of Histochemistry and Cytochemistry 38 1859-1877

Wooding FBP (1992) Current topic: the synepitheliochorial placenta of ruminants: binucleate cell fusions and hormone production Placenta 13 101-113

Wooding FBP and Beckers JF (1987) Trinucleate cells and the ultrastructural localization of bovine placental lactogen Cell and Tissue Research 247 667-673

Wooding FBP and Flint APF (1994) Placentation. In Marshall's Physiology of Reproduction 4th Edn pp 233-460 Ed. GH Lamming. Chapman and Hall, London

Wooding FB, Morgan G, Forsyth IA, Butcher G, Hutchings A, Billingsley SA and Gluckman PD (1992) Light and electron microscopic studies of cellular localization of oPL with monoclonal and polyclonal antibodies Journal of Histochemistry and Cytochemistry 40 1001-1009

Yamakawa M, Tanaka M, Koyama M, Kagesato Y, Watahiki M, Yamamoto $\mathbf{M}$ and Nakashima K (1990) Expression of new members of the prolactin growth hormone gene family in bovine placenta Journal of Biological Chemistry 265 8915-8920

Zieler CG, Kessler MA and Schuler LA (1990) Characterization of a novel prolactin-related protein from bovine fetal placenta Endocrinology $\mathbf{1 2 6}$ 2377-2382

Zoli AP, Demez P, Beckers JF, Reznik M and Beckers A (1992) Light and electron microscopic immunolocalization of bovine pregnancyassociated glycoprotein in the bovine placentome Biology of Reproduction 46 623-629

Received 18 February 2002.

First decision 24 April 2002.

Revised manuscript received 20 May 2002.

Accepted 31 May 2002. 